7. Kanishevska L. V. Doslidzhennia problemy vykhovannia sotsialnoi zrilosti starshoklasnykiv shkilinternativ / L. V. Kanishevska. // Pedahohichnyi almanakh : zb. nauk. prats. Kherson KVNZ "Khersonska akademiia neperervnoi osvity", 2012. - Vyp. 16. - S. 213-220.

8. Kanishevska Liubov. The formation of the immunity to the use of psychoactive substances by senior teenagers as the tendency of the formation of the life safety / Liubov Kanishevska. // Topical is sueso feducation: Collective monograph. - Pegasus Publishing, Lisbon, Portugal, 2018. P. 231-243.

9. Kon I. S. Psihologiya starsheklassnika / I. S. Kon. - M. : Prosveschenie, 1982 - 207 s.

10. Liashchuk O. S. Profilaktyka shkidlyvykh zvychok v uchniv $5-6$ klasiv shkil-internativ u pozaurochnii diialnosti: dys. ... kand.. ped. nauk : spets. 13.00.07 "Teoriia i metodyka vykhovannia" / O. S. Liashchuk. - Uman, 2017. $-246 \mathrm{~s}$.

11. Maksimova N. Yu. SotsIalno-psihologIchniy aspekt adiktivnoYi povedInki pIdlItkIv ta molodI. / N. Yu. Maksimova, S. V. Tolstouhova. - K., 2000. $-200 \mathrm{~s}$

12. Orzhekhovska V.M. Formuvannia zdorovoho sposobu zhyttia: stratehiia rozvytku / V. M. Orzhekhovska // Naukovyi svit. - 2008. - № 10. - S. 28-30

13. Pyvnyi alkoholizm : symptomy, oznaky, naslidky ta likuvannia - Rezhym dostupa: http : // hollydolly.com.ua/pivnij-alkogolizm-simptomi-oznaki-na.html:

14. Podhod zhiznennyih situatsiy v profilaktike tabachnyih problem / red. Andreevoy T. I., Krasovskogo K. S. - K., 2000. - Ch. 1. $-140 \mathrm{~s}$.

15. Hudyakov A. V. Kliniko-sotsialnyie aspektyi formirovaniya i profilaktika zavisimosti ot psihoaktivnih veschestv u nesovershennoletnih: avtoref. dis. ... d-ra. med. nauk : spets. 14.00.45; 14.0018 "Narkologiya", "Psihiatriya" / A. V. Hudyakov; Ivanovskaya gosudarstvennaya meditsinskaya akademiya. M., 2003. -37 s.

Одержано статтю: 12.06 .2019

Прийнято до друку:26.06.2019

УДК 37013.42:37.018.265

DOI: $10.15330 /$ esu. $16.150-156$

\section{Іванна Кулик,}

кандидат педагогічних наук, доцент, ДВНЗ “Прикарпатський національний університет імені В. Стефаника" (м. Івано-Франківськ, Україна)

\section{Ivanna Kulyk,}

Candidate of pedagogical scienses $(\mathrm{PhD})$, Assosiate Proffesor, Vasyl Stefanyc Precarpathian National University (Ivano-Frankivsk, Ukraine) ivannakyluk@ukr.net

Марія Комановська, магістрантка, ДВНЗ “Прикарпатський національний університет імені В. Стефаника" (м. Івано-Франківськ, Україна)

\section{Mariia Komanovska,} master's, Vasyl Stefanyc Precarpathian National University (Ivano-Frankivsk, Ukraine) komanovska@icloud.com

\title{
ФОРМУВАННЯ ПЕДАГОГІЧНОЇ КУЛЬТУРИ У СПІЛКУВАННІ МАЙБУТНІХ СОЦАЛЬНИХ ПЕДАГОГІВ 3 БАТЬКАМИ УЧНІВ У ПРОЦЕСІ ФАХОВОГО НАВЧАННЯ
}

\section{FORMING OF PEDAGOGICAL CULTURE OF COMMUNICATION IN FUTURE SOCIAL PEDAGOGUES WITH PARENTS OF STUDENTS IN THE PROCESS OF STUDYING}

У статті висвітлено теоретичну підготовку майбутніх сочіальних педагогів до спілкувания з батьками учнів икіл. 
Організація та методика проведения досліджения грунтувалась на положениях про те, що зростання рівнів педагогічної культури спілкування студентів з батьками иколярів можливе завдяки удосконаленню системи професійно-педагогічної підготовки майбутніх сочіальних педагогів, ефективному поєднанню різноманітних форм і методів вивчення сочіально-педагогічних дисииплін, реалізачії індивідуально-творчого підходу до навчальновиховного прочесу студентів, оріснтачї на суб 'єктивну позиџію кожного студента.

Розкрито організаційні форми $і$ методи педагогічної практики студентів у формуванні педагогічної культури спілкування з батьками учнів икіл.

Ключові слова: спілкування, педагогічне спілкування, культура педагогічного спілкування, соџіальний педагог, батьки.

The article outlines the theoretical training of future social educators for communication with parents of schoolchildren.

The organization and methodology of the research was based on the provisions that the growth of the levels of the pedagogical culture of communication between students and parents of schoolchildren is possible due to the improvement of the system of vocational and pedagogical training of future social educators, the effective combination of various forms and methods of studying social and pedagogical disciplines, the implementation of an individual and creative approach to the educational process of students, the orientation towards the subjective position of each student.

The organizational forms and methods of pedagogical practice of students in the formation of a pedagogical culture of communication with parents of schoolchildren are revealed.

Key words: commonunication, pedagogical commonunication, culture of pedagogical commonunication, social teacher, parents.

Актуальність постановки проблеми. Важливою умовою розвитку культури, освіти, демократичних, соціальних і економічних перетворень в Україні є підготовка висококваліфікованих кадрів. В успішному розв'язанні завдань національнокультурного, соціального і економічного відродження України значна роль належить соціальному педагогу.

Проте ще і сьогодні в педагогічних вузах недостатньо розвиваються особисті якості майбутнього соціального педагога, його творча педагогічна індивідуальність. Сам характер підготовки соціальних педагогів у педвузах не сприяє виробленню в них системного бачення майбутньої соціально-педагогічної діяльності, формування багатьох якостей необхідних соціальному педагогу в процесі його діяльності.

Неодмінною умовою ефективності цього процесу $\epsilon$ культура педагогічних кадрів, складовою частиною якої є спілкування.

Аналіз останніх досліджень і публікацій, у яких започатковано розв'язання проблеми. Проблема формування педагогічної культури спілкування в силу різних причин досліджувалась недостатньо. Сьогодні ж в умовах демократизації шкільного і вузівського життя вона набуває особливого значення. На перший план виступає дослідження питань спілкування випускників вузу, усвідомлення ними сутності і закономірностей цього процесу, з оволодіння відповідними вміннями, які відкривають нові можливості в розв'язанні проблем професійної підготовки майбутніх соціальних педагогів i значною мірою визначають іï успіх. Адже оволодіння умінням спілкуватись певним чином сприяє творчому, доброзичливому і діловому співробітництву між соціальним педагогом i учнями, соціальним педагогом і батьками учнів, соціальними педагогами і колегами.

Проблемам педагогічного спілкування в останні роки присвячено чимало наукових досліджень. Дослідження проблем педагогічного спілкування здійснюється 
на основі загальних закономірностей і механізмів його функціонування, розроблених в працях В.Кан-Калика, О.Киричука, К.Левітана, О. Леонтьєва, В. Маткіна, І.Синиці, П.Якобсона та ін.

Вагомий внесок в дослідження теорії і практики педагогічного спілкування, обгрунтування основних шляхів підготовки майбутніх педагогів до професійної діяльності зробили І.Бех, О.Бодальов, В.Киричук, А.Мудрик i iн. Педагогидослідники пропонують різні методи навчання студентів умінню педагогічного спілкування. Це використання ситуаційно-рольових ігор (А.Зязюн, А.Капська, П.Щербань і ін.); різних систем тренінгів (Т.Дроздова, В.Леві, О.Лєонтьєв); засобів театральної педагогіки (І.Зязюн, В.Абрамян); мікронавчання, демонстрування фрагментів фільму 3 наступним аналізом (Н.Кузьміна, К.Райан,); різного роду спецсемінари, спецкурси, практикуми (В.Кан-Калик, Г.Щукіна).

Проблема підготовки соціальних педагогів до роботи 3 батьками учнів досліджується в роботах Р.Войноли, Л.Міщенко, О.Пащенко, Т.Алєксєєнко, І.Трубавіної, І.Пєші, В.Кравця, І.Гребеннікова, В.Постового, О.Хромової і ін. В багатьох дослідженнях простежується ідея здійснення навчання й виховання дітей в рідному $і$ знайомому їм 3 ранніх років життя середовищі, що сприятиме максимальному зближенню сім'ї і школи на основі взаєморозуміння, взаємодопомоги, взаємодовіри.

Проблема підготовки майбутніх педагогів до професійного спілкування досліджується і зарубіжними вченими, зокрема американськими (Р.Блюм, А.Комбс, Р.Келлоу, Ю.Кім, А.Ньюмен, Д.Хонінг); польськими (Я.Восковський, А.Камінський, С.Ковальський та ін.).

Мета і завдання дослідження. Метою статті $\epsilon$ розкрити теоретичну підготовку соціальних педагогів до спілкування 3 батьками учнів шкіл, а також удосконалити організаційні форми і методи педагогічної практики студентів у формуванні педагогічної культури спілкування з батьками учнів шкіл.

Виклад основного матеріалу. Організація та методика проведення дослідження грунтувалась на положеннях про те, що зростання рівнів педагогічної культури спілкування студентів 3 батьками школярів можливе завдяки удосконаленню системи професійно-педагогічної підготовки майбутніх соціальних педагогів, ефективному поєднанню різноманітних форм i методів вивчення соціальнопедагогічних дисциплін, реалізації індивідуально-творчого підходу до навчально-виховного процесу студентів, орієнтації на суб'єктивну позицію кожного студента [4].

В основі організації і здійснення спілкування майбутніх соціальних педагогів 3 батьками учнів лежать знання про сучасну сім'ю, іiі виховний вплив на дитину, атмосферу спілкування батьків і дітей, характер ставлення батьків до дітей, рівень психолого-педагогічних знань і вмінь батьків, знання основ педагогічної культури спілкування $з$ батьками учнів. Тому у вивченні студентами педагогічних дисциплін ми основну увагу зосереджували на засвоєнні ними необхідних знань для здійснення спілкування 3 батьками школярів на професійному рівні, залучали студентів до науково-дослідної роботи 3 питань взаємодії сім'ї i школи, організовували пропаганду педагогічних знань студентами серед батьків учнів шкіл.

Зміст експериментальної діяльності 3 формування у студентів педагогічної культури спілкування з батьками школярів ми досліджували як підсистему цілісної системи професійно-педагогічної підготовки майбутніх соціальних педагогів. 3 метою найбільш повного врахування специфіки формування кожного показника педагогічної культури спілкування студентів з батьками школярів, нами використовувались різні методи вивчення і аналізу педагогічної інформації (спосте- 
реження, анкетування, практичні роботи, роботи пов'язані з розв'язуванням педагогічних задач, бесіди, тренінги, педагогічні ігри, аналіз і оцінка результатів виконання студентами практичних завдань, аналіз звітної документації і результатів педагогічної практики).

Розроблюючи зміст експериментальної роботи ми опирались на такі положення [2]:

1. Педагогічна культура спілкування майбутнього соціального педагога 3 батьками школярів формується на основі системи знань про сучасну сім'ю, особливості спілкування з нею, постійну практичну діяльність студентів;

2. Процес формування педагогічної культури спілкування студентів 3 батьками школярів тісно пов'язаний з розвитком педагогічних здібностей, спрямованістю на соціально-педагогічну діяльність;

3. Спілкування соціального педагога 3 батьками учнів $є$ процесом творчим і це найчастіше проявляється в пошуку оптимального варіанту розв'язання конкретних педагогічних ситуацій;

4. Формування педагогічної культури спілкування майбутніх соціальних педагогів з батьками учнів $є$ процесом керованим, що зумовлює необхідність вдосконалення спеціальної підготовки у ВНЗ.

Знання педагога мають забезпечувати регуляцію соціально-педагогічної діяльності і мати такі якості: систематичність, усвідомленість, міцність, оперативність, повноту тощо. Міцність знань полягає в умінні при потребі їх використовувати, а оперативність - це швидкість і точність їх застосування. Повнота знань пов'язується 3 поінформованістю соціального педагога в багатьох галузях науки, досягненнях педагогічної літератури, педагогічного досвіду.

Для формування таких знань у студентів потрібно, щоб інформація при сприйманні нібито "примірялась" до дії, тобто, до безпосередньої діяльності 3 батьками школярів. Педагогічні дисципліни мають першочергове значення в оволодінні студентами необхідними знаннями для організації спілкування 3 батьками учнів.

У формуванні педагогічної культури спілкування студентів з батьками учнів чільне місце належить засвоєнню курсу "Педагогічна майстерність соціального педагога" [3]. У вивчення цього навчального предмету ми вважаємо за доцільне ввести такі питання:

1. Культура спілкування соціального педагога 3 батьками учнів - основа його педагогічної майстерності.

2. Культура мовлення соціального педагога - як основна умова педагогічної культури спілкування з батьками школярів.

3. Особливості організації спілкування соціального педагога 3 батьками важковиховуваних дітей.

4. Основні умови організації процесу спілкування соціального педагога з батьками школярів.

5. Педагогічний такт - як головна умова налагодження і підтримки психологічного контакту з батьками учнів.

3 проблемою формування педагогічної культури спілкування 3 батьками школярів студенти спеціальності “Соціальна робота" освітня програма "Соціальна педагогіка" Прикарпатського національного університету імені Василя Стефаника мають можливість глибше ознайомитися вивчаючи курс "Основи психологопедагогічної культури батьків". Даний курс передбачає вивчення наступних тем: 
1. Сучасна сім'я і їі особливості.

2. Методика вивчення соціальним педагогом сімей учнів.

3. Організація педагогічної освіти батьків учнів.

4. Реалізація змісту педагогічної освіти батьків.

5. Педагогічна культура спілкування вчителя з батьками школярів.

6. Колективні форми спілкування соціального педагога з батьками школярів.

7. Індивідуальне спілкування вчителя з батьками учнів.

8. Навчально-педагогічні ігри в спілкуванні з батьками учнів.

Зміст курсу відображає також між предметні і внутрішньо предметні зв'язки. Вихідними принципами для цього є: узгодженість вивчення матеріалу 3 іншими предметами психолого-педагогічного курсу; забезпечення наступності в формуванні необхідних знань, набутих раніше; уникнення дублювання у вивченні питань, які розглядались раніше.

Для більш детального ознайомлення студентів 3 проблематикою взаємовідносин сім'ї і школи, виховання дітей батьками, спілкування соціального педагога і батьків учнів ми розробили тематику наукових робіт, зокрема:

1. Особливості виховання дітей в сім'ї українського народу з найдавніших часів до XXI століття.

2. Т.Шевченко про значення і роль сімейного виховання.

3. А.Макаренко про виховання дітей в сім'ї.

4. В.Сухомлинський про характер спілкування педагога з батьками учнів.

5. Педагогічний такт соціального педагога у спілкуванні з родиною учня.

6. Особистості спілкування соціального педагога 3 батьками педагогічно занедбаних дітей.

7. Етико-естетична спрямованість педагогічного спілкування.

8. Культура мовлення соціального педагога у спілкуванні з батьками учнів.

Однісю з найбільш ефективних форм організації підготовки студентів, спрямованої на формування у них педагогічної культури спілкування 3 батьками школярів $\epsilon$ педагогічна практика в загальноосвітній школі. Як правило, вона проводиться в умовах, близьких до самостійної педагогічної діяльності, де необхідно спілкуватись не лише 3 учнями, але і 3 їх батьками. Передовий досвід вищої педагогічної школи вказує на важливе значення навчально-виховної практики в системі професійно-соціально-педагогічної підготовки майбутніх соціальних педагогів. Формування педагогічної культури спілкування студентів 3 батьками учнів вимагає чіткої, глибоко продуманої системи їх практичної підготовки.

Педагогічна практика в школі є своєрідним ланцюжком взаємозв'язку теоретичного навчання студентів і змісту їх майбутньої роботи в школі як з учнями, так i їх батьками.

Незважаючи на складність проведення педагогічної практики, організації спілкування студентів з батьками школярів, ми намагались розробити й визначити певну систему. Ця система передбачала попередню підготовку керівників педагогічної практики, адміністрації школи, методистів і класних керівників школи, а також студентів до їі проведення.

В підготовці керівників педагогічної практики студентів ми рекомендуємо проводити семінари 3 методистами педпрактики, на яких розглядалися б такі питання: загальні завдання педагогічної практики і місце в ній спілкування студентів з батьками учнів; основні завдання організації спілкування майбутніх соціальних 
педагогів і батьків учнів; критерії оцінки сформованості у студентів педагогічної культури спілкування з батьками школярів.

Підготовка студентів до проходження педагогічної практики в школі полягала в: проведенні колоквіумів з питань організації і здійснення різних форм спілкування студентів 3 батьками школярів; проведенні науково-практичної конференції 3 основних питань педагогічної практики; наданні кожному студентові системи завдань 3 питань організації спілкування 3 батьками школярів, методичних рекомендацій, пам'яток тощо.

У підготовці студентів до літньої педагогічної практики в дитячих оздоровчих таборах та на шкільних майданчиках ми внесли для вивчення такі питання: особливості взаємовідносин вихователя з батьками дітей в таборах; організація індивідуального спілкування з батьками дітей в батьківський день; врахування вікових особливостей дітей у спілкуванні вихователя 3 їх батьками. Зміст спілкування в умовах оздоровчих таборів та шкільних майданчиків.

Висновки. Ефективність формування у студентів майбутніх соціальних педагогів педагогічної культури спілкування в процесі навчання забезпечується специфічними умовами і системою конкретних засобів, поєднанням різних форм i методів їх навчально-пізнавальної і практичної діяльності. Оволодіння студентами педагогічною культурою спілкування з батьками школярів повинно здійснюватись за умов індивідуально-особистісного засвоєння знань і вмінь. Такий підхід до організації підготовки майбутніх соціальних педагогів передбачає сформованість в них таких соціально-значимих якостей, як самосвідомість, світогляд, самостійність. Це в свою чергу сприяє професійній самореалізації, вмінню проявити їх. Визначення в професійній діяльності дозволяє виробити систему цінностей, яка може знайти засоби самовираження i в процесі спілкування. Зрозуміло, що формування у студентів педагогічної культури спілкування 3 батьками учнів дасть позитивні результати, якщо їм уже в роки навчання в ВУЗІ будуть створені умови, наближені до їх майбутньої професійної діяльності.

Головними умовами, які забезпечують формування у студентів педагогічної культури спілкування з батьками учнів $є$ : реалізація можливостей всіх педагогічних дисциплін; оптимальне поєднання різних форм навчання студентів (індивідуальних, групових, фронтальних); організація самостійної наукової діяльності студентів 3 досліджуваної проблеми; самовдосконалення студентів; вироблення конкретних завдань і методичних рекомендацій студентам на період педагогічної практики в школі.

1. Євтух М., Культура взаємин. Частина 1. Самопізнання: підруч. Горлівка: Видавництво ГДПІІМ, 2008. 228 с.

2. Культура общения учителя. (Под. ред. И.А.Зязюна). // Нар. образование, 1990. № 6. С. 38-45.

3. Педагогічна майстерність: підруч. / [І.А.Зязюн, Л.В. Крамущенко, І.Ф. Кривонос; за ред. І.А. Зязюна]. К.: Вища шк., 1997. 349 с.

4. Шанскова Т.І. Соціально-педагогічна підготовка до роботи з батьками учнів: метод. рек. для студ. і викл. ф-тів підготовки майбутніх учителів поч. кл. / за ред. О.А. Дубасенюк / T.I. Шанскова. Житомир: ЖДПУ, 2000. 100 с.

\section{References}

1. Ievtukh M., Kultura vzaiemyn. Chastyna 1. Samopiznannia: pidruch. Horlivka: Vydavnytstvo HDPIIM, 2008. $228 \mathrm{~s}$.

2. Kultura obshchenyia uchytelia. (Pod red. Y.A.Ziaziuna). // Nar. obrazovanye, 1990. № 6. S. 38-45.

3. Pedahohichna maisternist: pidruch. / [I.A.Ziaziun, L.V. Kramushchenko, I.F. Kryvonos; za red. I.A. Ziaziuna]. K.: Vyshcha shk., 1997. 349 s. 
4. Shanskova T.I. Sotsialno-pedahohichna pidhotovka do roboty z batkamy uchniv: metod. rek. dlia stud. i vykl. f-tiv pidhotovky maibutnikh uchyteliv poch. kl. / za red. O.A. Dubaseniuk / T.I. Shanskova. Zhytomyr: ZhDPU, 2000. 100 s.

Одержано статтю: 16.05 .2019

Прийнято до друку: 30.05.2019

УДК 37.013 .42

DOI: $10.15330 /$ esu. 16.156-166

\section{Галина Лемко,}

кандидат педагогічних наук, доцент,

ДВНЗ "Прикарпатський національний університет ім.В.Стефаника" (м. Івано-Франківськ, Україна)

Galyna Lemko,

Candidate of pedagogical scienses $(\mathrm{PhD})$,

Assosiate Proffesor, Vasyl Stefanyc Precarpathian

National University (Ivano-Frankivsk, Ukraine)

halyna.lemko@pu.if.ua

\section{Михайло Гундяк,}

студент, ДВНЗ “Прикарпатський національний

університет ім.В.Стефаника"

(м. Івано-Франківськ, Україна)

Mykhailo Hundiak,

student, Vasyl Stefanyc Precarpathian National

University (Ivano-Frankivsk, Ukraine)

hundiak.1997@gmail.com

\section{ПСИХОКОРЕКЦЙНА РОБОТА 3 СОЦАЛЬНО ДЕЗАДАПТОВАНИМИ ПІДЛІТКАМИ}

\section{PSYCHO-CORRECTIVE WORK WITH SOCIALLY UNADAPTED TEENS}

Стаття присвячена одній з актуальних проблем сочіальної педагогіки - проблема психокорекиійної роботи з дезадаптованими підлітками. На основі теоретичних та соиіально-психологічних досліджень розкриваються ті важливі значення, які характеризують психокорекиійу роботу з сочіально дезадаптованими підлітками. В роботі досліджено та проаналізовано особливості психокорекиійної роботи сочіального педагога з сочіально дезадаптованими підлітками, визначено сутність та завдання соиіальнопедагогічної роботи з дітьми різной форми дезадаптованої поведінки.

Сочіальному педагогу, який працюе в системі освіти, консультативних службах, реабілітаційних чентрах, часто доводиться проводити психокоригуючу роботу. Метою діяльності сочіального педагога є допомога в усуненні перешкод, ио заважають успіиному самостійному рухові підлітка у світі. Правильно організована сочіально-педагогічна діяльність спрямовуеться на надання комплексної допомоги у розв'язанні особистісних проблем того чи іниого клієнта.

Психокорекиійна робота з підлітками заснована на таких же принципах, що й з дітьми, однак, додаються нові компоненти, що відповідають віку. Приступаючи до роботи, сочіальний педагог та психолог завжди повинні пам'ятати, ио головне у відносинах з підлітком-че взаємоповага й довіра.

Проведений аналіз існуючих підходів до вивчення проблеми психологічної корекиії особистості сочіально дезадаптованих неповнолітніх показав, що важливим фактором корекиії дезадаптованої поведінки є сочіальний контроль. Сутність сочуіального контролю в тому, ио він передбачас зусилля найближчого сочіального оточения, спрямовані на 